Full length article

\title{
Betulinic acid derivative BA5, a dual NF-kB/calcineurin inhibitor, alleviates experimental shock and delayed hypersensitivity
}

\author{
Cássio Santana Meira ${ }^{\mathrm{a}}$, Renan Fernandes do Espírito Santo ${ }^{\mathrm{a}, \mathrm{b}}$, Tatiana Barbosa dos Santos ${ }^{\mathrm{a}, \mathrm{c}}$, \\ Iasmim Diniz Orge ${ }^{\mathrm{a}, \mathrm{d}}$, Dahara Keyse Carvalho Silva ${ }^{\mathrm{a}, \mathrm{c}}$, Elisalva Teixeira Guimarães ${ }^{\mathrm{a}, \mathrm{c}}$, \\ Luciana Souza de Aragão França ${ }^{\mathrm{d}}$, José Maria Barbosa-Filho ${ }^{\mathrm{e}}$, \\ Diogo Rodrigo Magalhães Moreira ${ }^{a}$, Milena Botelho Pereira Soares ${ }^{\mathrm{a}, \mathrm{d}, *}$
}

a Instituto Gonçalo Moniz, Fundação Oswaldo Cruz (FIOCRUZ), Salvador, BA, Brazil

b Faculdade de Farmácia, Universidade Federal da Bahia, Salvador, BA, Brazil

c Departamento de Ciências da Vida, Universidade do Estado da Bahia, Salvador, BA, Brazil

d Centro de Biotecnologia e Terapia Celular, Hospital São Rafael, Salvador, BA, Brazil

e Laboratório de Tecnologia Farmacêutica, Universidade Federal da Paraíba, João Pessoa, PB, Brazil

\section{A R T I C L E I N F O}

\section{Keywords:}

Betulinic acid derivative

T lymphocyte activation

Delayed type hypersensitivity, LPS-induced

endotoxin shock

\begin{abstract}
A B S T R A C T
Betulinic acid (BA) is a naturally occurring triterpenoid with several biological properties already described, including immunomodulatory activity. Here we investigated the immunomodulatory activity of eight semisynthetic amide derivatives of betulinic acid. Screening of derivatives BA1-BA8 led to the identification of compounds with superior immunomodulatory activity than BA on activated macrophages and lymphocytes. $\mathrm{BA5}$, the most potent derivative, inhibited nitric oxide and TNF $\alpha$ production in a concentration-dependent manner, and decreased NF-kB activation in Raw 264.7 cells. Additionally, BA5 inhibited the proliferation of activated lymphocytes and the secretion of IL-2, IL-4 IL-6, IL-10, IL-17A and IFNY, in a concentration-dependent manner. Flow cytometry analysis in lymphocyte cultures showed that treatment with BA5 induces cell cycle arrest in pre-G1 phase followed by cell death by apoptosis. Moreover, BA5 also inhibited the activity of calcineurin, an enzyme that plays a critical role in the progression of cell cycle and T lymphocyte activation. BA5 has a synergistic inhibitory effect with dexamethasone on lymphoproliferation, showing a promising profile for drug combination. Finally, we observed immunosuppressive effects of BA5 in vivo in mouse models of lethal endotoxemia and delayed type hypersensitivity. Our results reinforce the potential use of betulinic acid and its derivatives in the search for potent immunomodulatory drugs.
\end{abstract}

\section{Introduction}

Betulinic acid (BA) is a naturally occurring pentacyclic triterpenoid found in several plant species, which can be alternatively prepared from its metabolic precursor, betulin (Yogeeswari and Sriram, 2005). This natural product holds several biological activities, including anticancer, anti-HIV, antiparasitic and anti-angiogenic activities (Takada and Aggarwal, 2003; Dehelean et al., 2011; Ali-Seyed et al., 2016; Li et al., 2016; Meira et al., 2016). In particular, BA has been reported to possess cytotoxic effects on several tumor cell lines of different origins, as well as in animal models of cancer (Gheorgheosu et al., 2016).

BA has also been investigated as an immunomodulatory agent (Sultana and Saify, 2012). More specifically, BA inhibits the production of several inflammatory mediators, including nitric oxide (NO), prostaglandin $\mathrm{E}_{2}\left(\mathrm{PGE}_{2}\right)$, tumor necrosis factor alpha (TNF $\left.\alpha\right)$, interleukin (IL)-6 and IL-1ß (Jingbo et al., 2015; Kim et al., 2016). Most of these effects are related to the inhibition of nuclear factor- $\mathrm{\kappa B}(\mathrm{NF}-\mathrm{\kappa B})$, a transcription factor involved in the regulation of several pro-inflammatory genes, in particular TNFa (Viji et al., 2010; Kim et al., 2016). BA is also known to suppress STAT3 signaling, which is essential transcription factor for differentiation of the $\mathrm{CD}^{+}{ }^{+}$Th17 cells in a variety of autoimmune diseases (Blaževski et al., 2013).

In addition, in a cecal ligation and puncture mouse model, it has been demonstrated that BA treatment reduces mortality and ameliorates lung and kidney function by down-regulating NF-kB (Lingaraju et al., 2015a, b). Furthermore, in lipopolysaccharide (LPS)-induced endotoxin shock, pre-treatment with BA significantly improves mice survival by modulating TNF $\alpha$ production by macrophages in vivo

\footnotetext{
* Correspondence to: Instituto Gonçalo Moniz, Fundação Oswaldo Cruz, Rua Waldemar Falcão, 121, Candeal, Salvador, Bahia 40296-710, Brazil.

E-mail address: milena@bahia.fiocruz.br (M.B.P. Soares).
} 
through a mechanism dependent on IL-10 (Viji et al., 2010; Costa et al., 2014). However, in a number of in vitro and in vivo models of inflammation, the anti-inflammatory activity of BA has been considered to be moderate (Cichewicz and Kouzi, 2004; Li et al., 2017).

In view of these findings, BA has been used as a prototype for the design and synthesis of more potent immunomodulatory agents. Chemical modifications of the carboxyl group have suggested that this part of BA molecule has potential for the production of derivatives with enhanced biological activity, including immunomodulatory agents (Sultana and Saify, 2012; Chen et al., 2017). Based on these facts, the purpose of our work was to evaluate the immunomodulatory potential of new semi-synthetic amide derivatives of betulinic acid in vitro and in vivo, as well as their mechanisms of action.

\section{Materials and methods}

\subsection{Drugs}

Betulinic acid (BA) was extracted from the bark of Ziziphus joazeiro Mart. (Rhamnaceae) by using a previously described method (BarbosaFilho et al., 1985). Semi-synthetic compounds (BA1 to BA8; 94-98\% purity by high performance liquid chromatography) were prepared from betulinic acid, as previously described (Meira et al., 2016). Gentian violet (Synth, São Paulo, SP, Brazil) was used as positive control in the cytotoxicity assays. Dexamethasone (Sigma-Aldrich, St. Louis, MO), a synthetic glucocorticoid, was used as positive control in immunomodulatory assays. Cyclosporin A (Sigma-Aldrich) was used as positive control in calcineurin activity assay and in DTH assay. Mifepristone (RU 486; Sigma-Aldrich), an antagonist of glucocorticoid receptor, was used in mechanism assays. All compounds were dissolved in Dimethyl sulfoxide (DMSO; PanReac, Barcelona, Spain) and diluted in cell culture medium for use in the assays. The final concentration of DMSO was less than $0.1 \%$ in all in vitro experiments and less than $5 \%$ in all in vivo experiments.

\subsection{Animals}

BALB/c and C57BL/6 mice 4-12 weeks old) were bred and maintained at the Gonçalo Moniz Institute (Oswaldo Cruz Foundation, Bahia, Brazil) in sterilized cages, under a controlled environment and receiving a balanced rodent diet and water ad libitum. All animal experiments and procedures were approved by the institution's committee on the ethical handling of laboratory animals (Approved number: LIGM-018/15).

\subsection{Cytotoxicity to mammalian cells}

Cytotoxicity of the compounds was determined using the rat cardiomyoblast H9c2 and the monkey kidney LCC-MK2 cell lines. Cells were seeded into 96-well plates at a cell density of $1 \times 10^{4}$ cells/well in Dulbecco's modified Eagle medium (DMEM; Life Technologies, GIBCOBRL, Gaithersburg, MD) supplemented with $10 \%$ fetal bovine serum (FBS; GIBCO) and $50 \mu \mathrm{g} / \mathrm{ml}$ of gentamicin (Life, Carlsbad, CA) and incubated for $24 \mathrm{~h}$ at $37{ }^{\circ} \mathrm{C}$ and $5 \% \mathrm{CO}_{2}$. The compounds tested were then added $(10-0.04 \mu \mathrm{M})$, in quadruplicate, and incubated for $72 \mathrm{~h}$. One $\mu \mathrm{Ci}$ of ${ }^{3} \mathrm{H}$-thymidine (Perkin Elmer, Waltham, MA) was added to each well, incubated for $18 \mathrm{~h}$, frozen at $-20{ }^{\circ} \mathrm{C}$ and subsequently thawed and the contents transferred to UniFilter-96 GF/B PEI coated plates (PerkinElmer) using a cell harvester. After drying, $50 \mu \mathrm{l}$ of scintillation cocktail (MaxiLight, Hidex, Turku, Finland) was added in each well, sealed and plate read in a liquid scintillation microplate counter (Chameleon, Turku, Finland). Cell viability was measured as the percent of ${ }^{3} \mathrm{H}$-thymidine incorporation for treated-cells in comparison to untreated cells. Gentian violet was used as positive control, at concentrations ranging from 0.04 to $10 \mu \mathrm{M}$. Cytotoxicity concentration at $50 \%\left(\mathrm{CC}_{50}\right)$ values were calculated using data from three independent experiments.

In addition, the cytotoxicity of compounds was also determined in peritoneal macrophages. Cells were obtained by washing, with cold phosphate buffered saline (PBS), the peritoneal cavity of BALB/c mice 4-5 days after injection of $3 \%$ thioglycolate (Sigma-Aldrich) in saline (1.5 ml per mice). Then, cells were seeded into 96-well plates at a cell density of $2 \times 10^{5}$ cells/well in DMEM supplemented with $10 \%$ FBS and $50 \mu \mathrm{g} / \mathrm{ml}$ of gentamycin and incubated for $24 \mathrm{~h}$ at $37^{\circ} \mathrm{C}$ and $5 \%$ $\mathrm{CO}_{2}$. After that time each test inhibitors were added at least in six concentrations $(20-0,15 \mu \mathrm{M})$ in triplicate and incubated for $24 \mathrm{~h}$. $20 \mu \mathrm{l} /$ well of AlamarBlue (Invitrogen, Carlsbad, CA) was added to the plates during $10 \mathrm{~h}$. Colorimetric readings were performed at 570 and $600 \mathrm{~nm}$. $\mathrm{CC}_{50}$ values were calculated using data-points gathered from three independent experiments.

\subsection{Macrophage cultures}

Peritoneal exudate macrophages were seeded in 96-well plates at 2 $\times 10^{5}$ cells/well in DMEM medium supplemented with $10 \%$ of FBS and $50 \mu \mathrm{g} / \mathrm{ml}$ of gentamicin for $2 \mathrm{~h}$ at $37^{\circ} \mathrm{C}$ and $5 \% \mathrm{CO}_{2}$. Plates were washed to remove non-adherent cells, and the remaining cells were then stimulated with LPS ( $500 \mathrm{ng} / \mathrm{ml}$, Sigma-Aldrich) and interferon gamma (IFN $\gamma ; 5 \mathrm{ng} / \mathrm{ml}$, Sigma-Aldrich) in the absence or presence of compounds at different concentrations, and incubated at $37^{\circ} \mathrm{C}$. Cell-free supernatants were collected $4 \mathrm{~h}$ (for TNF $\alpha$ measurement) and $24 \mathrm{~h}$ (for $\mathrm{IL}-1 \beta, \mathrm{IL}-10$ and nitrite quantifications), and kept at $-80{ }^{\circ} \mathrm{C}$ until use.

\section{5. $N F-\kappa B$ luciferase assay}

The murine mouse leukemic monocyte macrophage cell line Raw 264.7 Luc cells bearing the pBIIX-luciferase (pBIIX-luc) targeting vector containing the firefly luciferase gene (luc) driven by two NF-kB binding sites from the kappa light chain enhancer in front of a minimal fos promoter (Zhong et al., 1997) were kindly provided by Maria Célia Jamur (University of São Paulo, Ribeirão Preto, Brazil). The cells were cultured in RPMI medium (Sigma) supplemented with 20\% FBS and $50 \mu \mathrm{g} / \mathrm{ml}$ gentamicin in 24 -well plates at $37^{\circ} \mathrm{C}$ in a humidified environment containing $5 \% \mathrm{CO}_{2}$. For luciferase reporter assays, $5 \times 10^{5}$ cells $/ \mathrm{ml}$ were pretreated with different concentrations of BA5 $(20,10$ or $5 \mu \mathrm{M})$, BA $(20 \mu \mathrm{M})$ or dexamethasone $(20 \mu \mathrm{M})$ for $1 \mathrm{~h}$ prior to stimulation with LPS (500 ng/ml) and IFN $\gamma(5 \mathrm{ng} / \mathrm{ml})$ for $3 \mathrm{~h}$. After washing with cold PBS, cells were lysed by adding TNT lysis buffer $(200 \mathrm{mM}$ Tris, $\mathrm{pH}$ 8.0, $200 \mathrm{mM} \mathrm{NaCl}, 1 \%$ Triton $\mathrm{X}-100$ ) for $20 \mathrm{~min}$ at $4{ }^{\circ} \mathrm{C}$. The determination of the luciferase activity was performed using the Promega luciferase assay system (Promega, Madison, CA), according to the manufacturer's instructions. The samples were analyzed in a Globomax 20/20 Luminometer (Promega). Data are expressed as relative light units.

\subsection{Splenocyte cultures}

For lymphoproliferation assays, BALB/c splenocyte suspensions were prepared in DMEM medium supplemented with $10 \%$ of FBS and $50 \mu \mathrm{g} / \mathrm{ml}$ of gentamicin. Splenocytes $\left(1 \times 10^{6}\right.$ cells/well $)$ were plated in 96-well plates, in quadruplicate, and stimulated or not with concanavalin A (Con A; $2 \mu \mathrm{g} / \mathrm{ml}$, Sigma-Aldrich) or Dynabeads ${ }^{\circledR}$ mouse Tactivator CD3/CD28 (bead to cell ratio $=1: 1$; ThemoFisher Scientific, Waltham, MA). In some experiments, RU486, a glucocorticoid receptor antagonist (Sigma-Aldrich), was added to the cultures to investigate the mechanism of action of the most potent derivative. To evaluate the lymphoproliferation, splenocytes were activated in the absence or presence of various concentrations of derivatives $(500-0.0005 \mathrm{nM})$. After $48 \mathrm{~h}$ of incubation, $1 \mu \mathrm{Ci}$ of ${ }^{3} \mathrm{H}$ - thymidine was added to each well, incubated for $18 \mathrm{~h}$ and read, as described above. Cell proliferation was measured as the percent of ${ }^{3} \mathrm{H}$-thymidine incorporation for treated-cells in comparison to untreated cells. Dexamethasone was used as positive 
control. Inhibitory concentration at $50 \%\left(\mathrm{IC}_{50}\right)$ values were calculated using data from three independent experiments.

Splenocytes from BALB/c mice were also plated into 24-well plates at a cell density of $5 \times 10^{6}$ cells/ in DMEM medium supplemented with FBS containing or not $5 \mu \mathrm{g} / \mathrm{ml}$ of Con A in the absence or presence of different concentrations of BA5 (500, 50 and $5 \mathrm{nM})$, BA $(500 \mathrm{nM})$ and dexamethasone $(500 \mathrm{nM})$. After $48 \mathrm{~h}$, cell-free supernatants were collected and kept at $-80{ }^{\circ} \mathrm{C}$ until use for cytokine quantification.

\subsection{Mixed lymphocyte reaction (MLR)}

BALB/c mice were weekly immunized with intraperitoneal injections of $10^{7}$ splenocytes obtained from $\mathrm{C} 57 \mathrm{BL} / 6$, as previously described (Soares et al., 2006). After 3 weeks of immunization, mice were euthanized for spleen cell preparation in DMEM medium supplemented with $10 \%$ of FBS and $50 \mu \mathrm{g} / \mathrm{ml}$ of gentamicin. Spleen cells were plated in 96 well plates at a cell density of $1 \times 10^{6}$ cells/well in the absence or in the presence of irradiated C57BL/6 splenocytes at $10^{6}$ cells/well (dose of $3 \mathrm{~Gy}$ in a ${ }^{137} \mathrm{Cs}$ source irradiator purchased from CisBio International, Cordolet, France) and different concentrations of drugs in testing, in quadruplicates. After $72 \mathrm{~h}$ of incubation, ${ }^{3} \mathrm{H}$-thymidine was added to each well, and the plates were incubated for additional $18 \mathrm{~h}$. The incorporation of ${ }^{3} \mathrm{H}$-thymidine was determined as described above.

\subsection{Assessment of cytokine and nitric oxide production}

Cytokine concentrations in supernatants from peritoneal macrophages cultures collected at $4 \mathrm{~h}$ (for TNF $\alpha$ ) and $24 \mathrm{~h}$ (for IL- $1 \beta$ and IL10) and from splenocyte cultures (IL-2, IL-4, IL-6, IL-10, IL-17A and IFN $\gamma$ ) were determined by enzyme-linked immunosorbent assay (ELISA), using DuoSet kits from R \& D Systems (Minneapolis, MN), according to the manufacturer's instructions. Nitric oxide production was estimated in macrophage culture supernatants harvested at $24 \mathrm{~h}$ using the Griess method for nitrite quantification (Green et al., 1982).

\subsection{Flow cytometry analyses}

Splenocytes from BALB/c mice were plated into 24-well plates at a cell density of $5 \times 10^{6}$ cells/ in DMEM medium supplemented with $10 \%$ FBS containing $5 \mu \mathrm{g} / \mathrm{ml}$ of Con A in the absence or presence of different concentrations of BA5 (500, 50 and $5 \mathrm{nM}$ ) for 24 and $48 \mathrm{~h}$ for cell death determination and cell cycle analysis respectively. For cell death determination, cells were centrifuged and then pellet washed twice with cold PBS and initially labeled with APC anti-mouse CD3 (Biolegend, San Diego, CA) diluted 1:100 for $15 \mathrm{~min}$ followed by stained with propidium iodide (PI) and annexin V using the annexin VFITC apoptosis detection kit (Sigma-Aldrich), according to the manufacturer's instructions. For cell cycle analysis, cells were labeled with APC anti-mouse CD3 followed by a second stained with a solution of PBS with propidium iodide $(2 \mu \mathrm{g} / \mathrm{ml})$, RNAase $(100 \mu \mathrm{g} / \mathrm{ml})$ and $0.1 \%$ of Triton X-100 in the dark at $37^{\circ} \mathrm{C}$ for $30 \mathrm{~min}$. The cell preparations were analyzed using a FACS Calibur flow cytometer (Becton Dickinson, San Diego, CA). A total of 10,000 events positive for APC anti-mouse CD3 staining was acquired and data were analyzed using FlowJo software (Tree Star, Ashland, OR).

\subsection{Calcineurin activity}

The calcineurin phosphatase activity was measured in cell extracts using a Calcineurin Cellular Activity assay kit (Enzo Life Sciences, Farmingdale, NY). In brief, splenocytes from BALB/c mice were plated into 24-well plates at a cell density of $5 \times 10^{6}$ cells/ in DMEM medium supplemented with $10 \%$ FBS containing $5 \mu \mathrm{g} / \mathrm{ml}$ of Con A in the absence or presence of BA5 $(500,50$ and $5 \mathrm{nM}$ ), or cyclosporin A $(500 \mathrm{nM})$ for $48 \mathrm{~h}$. Then, cells were lysed in a buffer containing protease inhibitors, centrifuged and the supernatant was used for analysis.
The same amount of protein $(5 \mu \mathrm{g})$ per sample was used in the calcineurin activity assays. Colorimetric measurements were performed at $620 \mathrm{~nm}$. The amount of phosphate released by calcineurin was calculated using a standard curve.

\subsection{Drug combination assay}

For in vitro drug combinations, doubling dilutions of each drug (BA5 and dexamethasone), used alone or in fixed combinations were incubated with splenocytes followed the protocol described above. The analysis of the combined effects was performed by determining the combination index (CI), used as cutoff to determine synergism, by using Chou-Talalay CI method (Chou and Talalay, 2005) and through the construction of isobologram using the fixed ratio method, as described previously (Fivelman et al., 2004).

\subsection{LPS-induced endotoxic shock}

Groups of six male BALB/c mice (4 weeks of age) were used for the LPS lethality assays. Mice were treated with BA5 (50 or $25 \mathrm{mg} / \mathrm{kg}$ ), dexamethasone $(25 \mathrm{mg} / \mathrm{kg}$ ) or vehicle ( $5 \%$ of DMSO in saline), by intraperitoneal (i.p.) route. Ninety min later, animals were challenged with $600 \mu \mathrm{g}$ of LPS (from serotype 0111:B4 Escherichia coli, SigmaAldrich) in saline, by i.p. route. Survival was then monitored daily, during 4 days.

\subsection{Delayed type hypersensitivity (DTH) assay}

BALB/c mice (8-12 weeks of age) were sensitized by injecting $50 \mu \mathrm{g}$ of crystallized bovine serum albumin (BSA; Sigma-Aldrich) emulsified in $20 \mu \mathrm{l}$ of complete Freund's adjuvant (CFA; Sigma-Aldrich) subcutaneously into each side of the base of tail. Seven days later, animals were randomized into five groups and mice were treated with BA5 (50 or $25 \mathrm{mg} / \mathrm{kg}$ ), cyclosporin A (25 mg/kg), dexamethasone ( $25 \mathrm{mg} / \mathrm{kg}$ ) or vehicle (5\% of DMSO in saline), by the intraperitoneal route 24 and $3 \mathrm{~h}$ before challenge. DTH was elicited by injection of $30 \mu \mathrm{l}$ of a $2 \%$ suspension of heat-aggregated BSA in saline subcutaneously into the footpad, according to a previously reported method (Titus and Chiller, 1981). Before and $3 \mathrm{~h}$ post-challenge, footpad thickness was measured with calipers and swelling was calculated by subtracting the thickness of the footpad after challenge from that before challenge.

\subsection{Statistical analyses}

One-way analysis of variance and Newman-Keuls multiple comparison tests were employed by using Graph Pad Prism version 5.01 (Graph Pad Software, San Diego, CA). Differences were considered significant when the values of $P$ were $<0.05$.

\section{Results}

\subsection{Cytotoxicity and modulation of macrophage function in vitro by $B A$ derivatives}

In order to test the effects of the compounds in vitro, first we evaluated the cytotoxicity of compounds on peritoneal macrophages, LCCMK2 and H9c2 cells. As shown in Table 1, all compounds had no cytotoxic effect in the concentrations tested, which were used in the following in vitro assays.

All the compounds were initially evaluated in cultures of macrophages activated with LPS and IFN $\gamma$. Dexamethasone, a standard glucocorticoid, was used as positive control. As shown in Table 1, betulinic acid inhibited NO production in $45.1 \%$ at $10 \mu \mathrm{M}$. In contrast, most of derivatives showed a weak inhibitory activity of nitric oxide production, with the exception of BA5. This derivative inhibited in $53.0 \%$ the production of NO, more potently than the prototype molecule (BA) and 
Table 1

Screening of cytotoxicity and immunomodulatory activity of semi-synthetic derivatives of betulinic acid.<smiles>C=C(C)[C@@H]1CC[C@]2(C(=O)O)CC[C@]3(C)C(CCC4C3CCC3C(C)(C)[C@H](O)CC[C@]43C)C12</smiles>

\begin{tabular}{|c|c|c|c|c|c|c|}
\hline Compounds & $\mathbf{R}$ & $\begin{array}{c}\mathrm{CC}_{50}(\mu \mathrm{M}) \\
\mathrm{M}^{\mathrm{a}}\end{array}$ & $\begin{array}{l}\mathrm{CC}_{50}(\mu \mathrm{M}) \\
\mathrm{MK2} \text { cells }\end{array}$ & $\begin{array}{l}\mathrm{CC}_{50}(\mu \mathrm{M}) \\
\mathrm{H9c2} \text { cells }\end{array}$ & $\begin{array}{c}\text { Inhibition of } \\
\text { NO (\%) } \\
\text { production at } \\
10 \mu M^{\mathrm{c}} \\
\end{array}$ & $\begin{array}{c}\mathrm{IC}_{50}(\mathrm{nM}) \\
\text { Mitogen }^{\mathrm{d}} \\
\text { Induced }^{\mathrm{d}}\end{array}$ \\
\hline BA & $\mathrm{OH}$ & $>20$ & $>10$ & $>10$ & $45.1 \pm 1.9$ & $284.5 \pm 32.8$ \\
\hline BA1 & & $>20$ & $>10$ & $>10$ & $11.1 \pm 0.1$ & $>500$ \\
\hline BA2 & & $>20$ & $>10$ & $>10$ & $7.2 \pm 0.9$ & $>500$ \\
\hline BA3 & & $>20$ & $>10$ & $>10$ & $15.9 \pm 0.7$ & $>500$ \\
\hline BA4 & & $>20$ & $>10$ & $>10$ & $7.7 \pm 0.1$ & $>500$ \\
\hline BA5 & & $>20$ & $>10$ & $>10$ & $53.0 \pm 2.2$ & $14.3 \pm 0.91$ \\
\hline BA6 & & $>20$ & $>10$ & $>10$ & $25.9 \pm 2.7$ & $27.6 \pm 2.1$ \\
\hline BA7 7 & & $>20$ & $>10$ & $>10$ & $0 \pm 0.00$ & $>500$ \\
\hline BA8 & & $>20$ & $>10$ & $>10$ & $16.7 \pm 1.4$ & $58.7 \pm 4.9$ \\
\hline Dexa & - & $>20$ & $>10$ & $>10$ & $57.6 \pm 3.2$ & $6.9 \pm 0.4$ \\
\hline GV & - & - & $1.1 \pm 0.01$ & $1.5 \pm 0.32$ & - & - \\
\hline
\end{tabular}

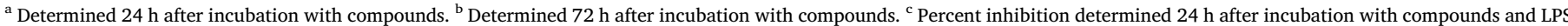

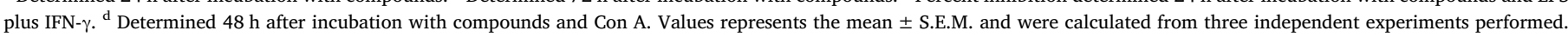

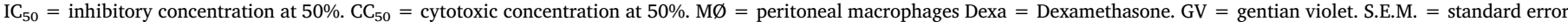
of mean.

close to that found for dexamethasone (57.6\% of inhibition at $10 \mu \mathrm{M})$. BA5 caused a concentration-dependent inhibition of NO and TNF $\alpha$ production (Figs. 1A and B). Additionally, the production of IL-10 was significantly reduced by BA5 and dexamethasone, while it was increased by BA (Fig. 1C).

LPS-induced Toll-like receptor-4 (TLR4) activation leads to triggering of intracellular signaling pathways, including NF-kB activation, consequently causing the transcriptional regulation of several inflammatory genes, including Tnf and Nos2 (Bartuzi et al., 2013). To investigate whether BA5 modulates NF-kB activation in macrophages, we performed an assay using RAW cells transduced with a reporter gene under the control of a promoter regulated by NF-kB. Addition of BA5 
A

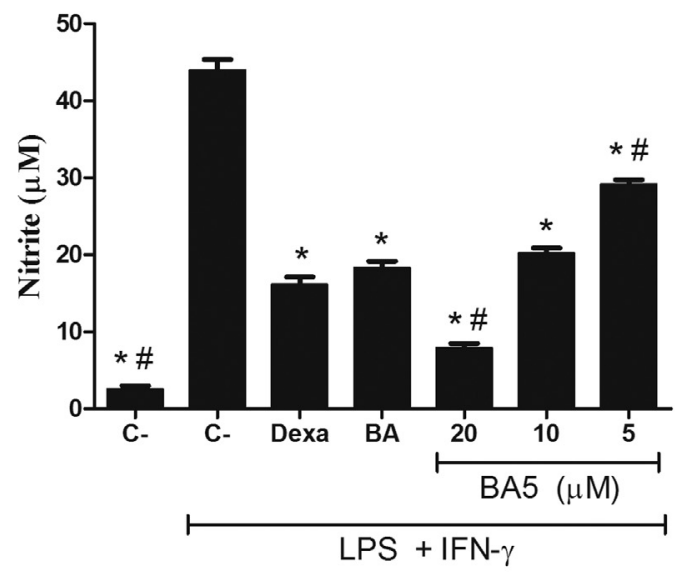

C

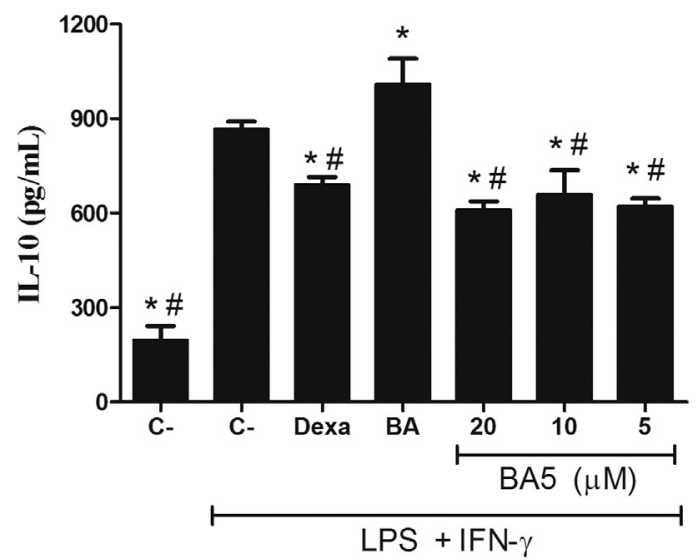

B

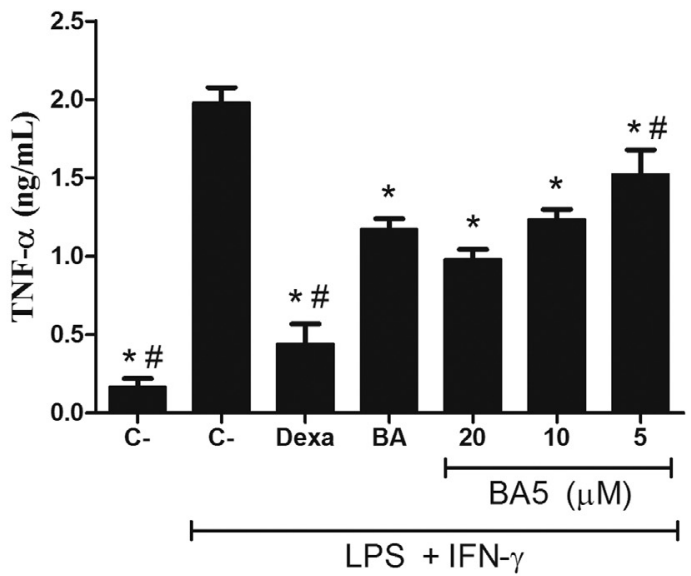

D

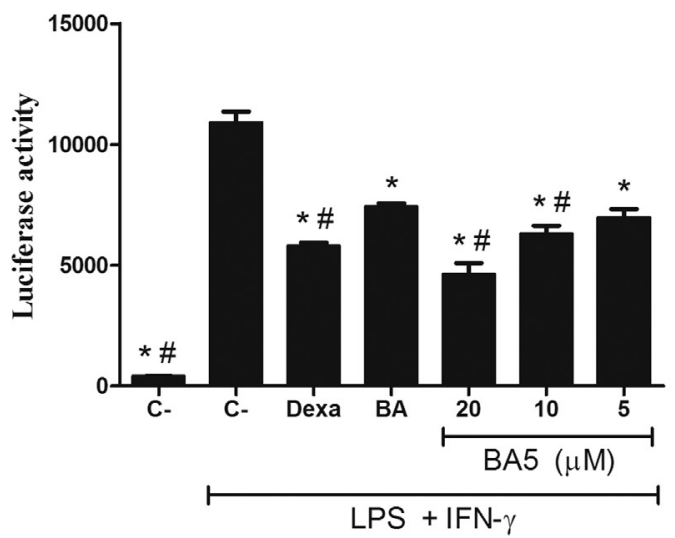

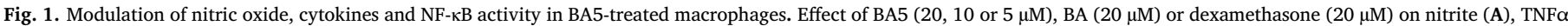

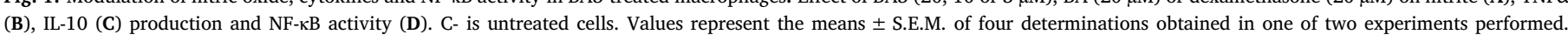
${ }^{*} P<0.05$ compared to stimulated and untreated cells; \#P<0.05 compared to BA-treated cells.

caused the reduction of NF-kB activation, in a concentration-dependent manner, in RAW cells stimulated with LPS and IFN $\gamma$. BA and dexamethasone also caused a significant reduction of luciferase activity (Fig. 1D).

\subsection{BA derivatives inhibit $T$ cell proliferation}

To evaluate the immunosuppressive effects of BA derivatives on lymphocytes, we first performed a Con A-induced lymphoproliferation assay. Screening of BA derivatives led to the identification of three compounds more active than BA (Table 1 ). The most active derivatives were BA5, BA6 and BA8, which present a morpholyl, thiomorpholyl and 4-methylphenylpiperidine groups, presented increased potency, especially the BA5 derivative, which had an $\mathrm{IC}_{50}$ value of $14.3 \mathrm{nM}$, close to that of dexamethasone $\left(\mathrm{IC}_{50}=6.9 \mathrm{nM}\right)$. Dexamethasone has a potent $\mathrm{T}$ cell proliferation inhibition activity (Table 1 ).

We further evaluated in splenocyte cultures activated with antiCD3/anti-CD28 coated-beads to evaluate the effect of BA5 on the proliferation of $\mathrm{CD}^{+}{ }^{+} \mathrm{T}$ lymphocytes. As shown in Fig. 2A, BA5 caused a concentration-dependent inhibition of lymphoproliferation, with higher potency $(P<0.05)$ than the prototype BA and similar to the activity observed for dexamethasone. Additionally, BA5 treatment inhibits in vitro alloreactive $\mathrm{T}$ cell response as demonstrated by a concentrationdependent reduction of proliferation in a mixed lymphocyte reaction (Fig. 2B).
3.3. BA5 modulates cytokine production and induces cell cycle arrest in activated $T$ cells

As a potential immunotherapeutic agent, it was also important to determine the effect of BA5 on cytokine secretion. To this end, cytokine production by splenocytes stimulated with Con A and treated with BA5 was investigated (Fig. 3). Compared to untreated and stimulated cultures, treatment with BA5 decreased the secretion of IL-2, IL-4, IL-6, IL10, IL-17A and IFN- $\gamma$ in a concentration dependent manner. Under the same conditions, dexamethasone also promoted a significant decrease in cytokine production. BA also decreased the production of most cytokines but less efficient when compared with BA5. Once again, BA treatment increased IL-10 production (Fig. 3D).

Flow cytometry analysis was carried out in splenocyte cultures in order to determine the effect of BA5 on cell cycle progression and cell death. Treatment with BA5 induced, in a concentration-dependent manner, cell cycle arrest on G0/G1 phase, accompanied by an increase in PreG1 phase (Figs. 4A and B). Moreover, the cell cycle arrest was accompanied by a significant and concentration-dependent increase in annexin V positive cells, which is a hallmark of apoptosis (Fig. 4C).

\subsection{BA5 effects on lymphocytes is independent of glucocorticoid receptor,} but affects calcineurin activity

To understand the mechanisms by which BA5 inhibits lymphocyte 
A

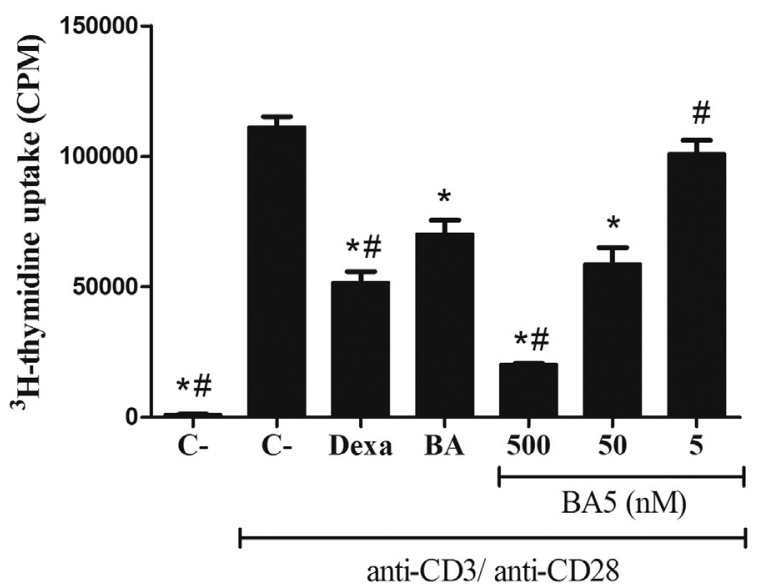

B

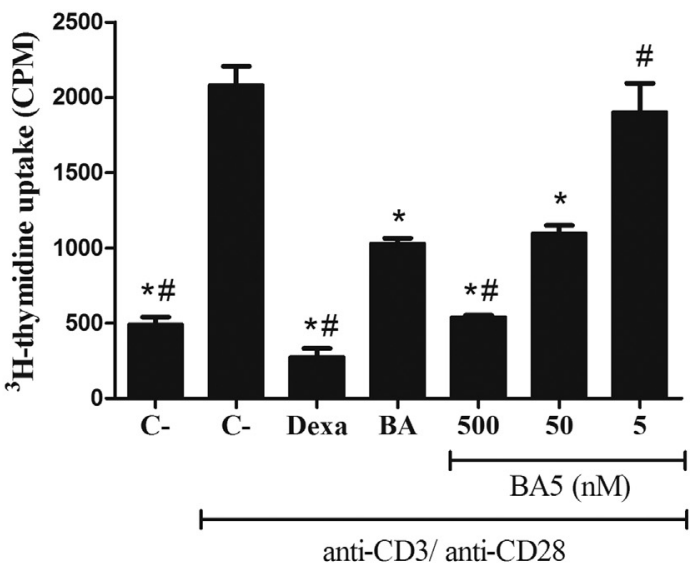

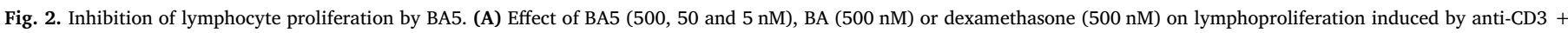

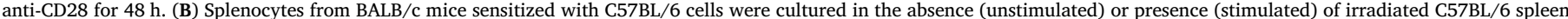

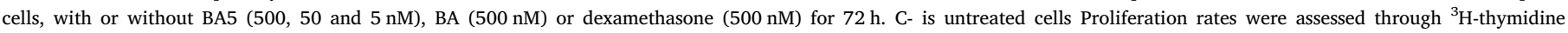

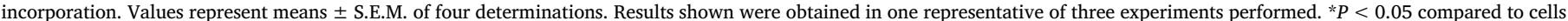
stimulated anti-CD3/anti-CD28 (A) or irradiated C57BL/6 spleen cells (B); \#P $<0.05$ compared to BA-treated cultures.

activation, we tested the ability of RU486, a glucocorticoid receptor antagonist, to reverse the effect of BA5 in Con A-stimulated splenocyte cultures. As shown in Fig. 5, addition of RU486 inhibited spleen cell proliferation. This is a glucocorticoid receptor (GR) antagonist which can block the effect of GR agonists, such as dexamethasone. However, it presents off-targets effects, which lead to an attenuation of T cell proliferation (Chien et al., 2009). When co-treated with dexamethasone, addition of RU486 promoted a partial block of dexamethasone activity. In contrast, the inhibition of spleen cell proliferation upon Con A activation by BA5 was not reversed under RU486 co-treatment.

We also investigated the effect of BA5 on calcineurin activity, which leads to the activation of Nuclear factor of activated T-cells (NFAT), a transcription factor involved in $\mathrm{T}$ cell activation (Macian, 2005). As shown in Fig. 6, treatment with BA5 decreased the activity of this
A

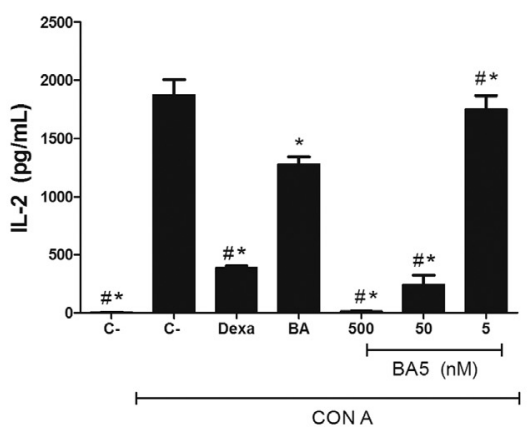

D

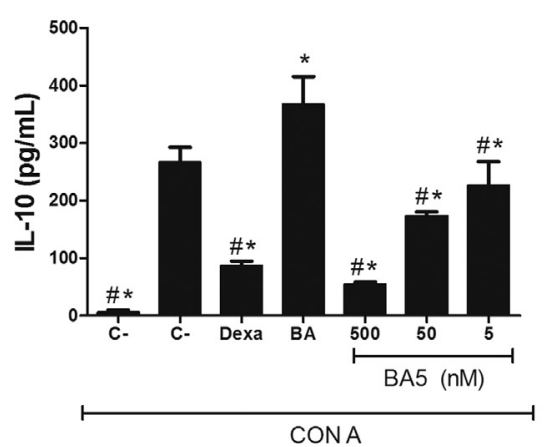

B

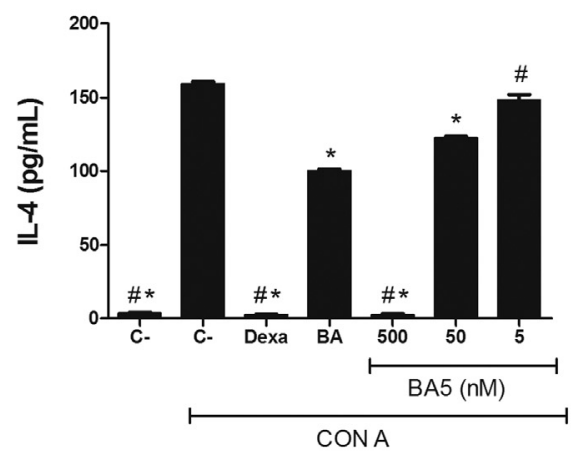

E

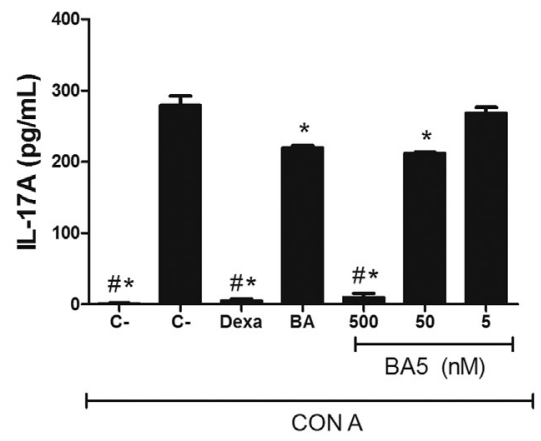

C

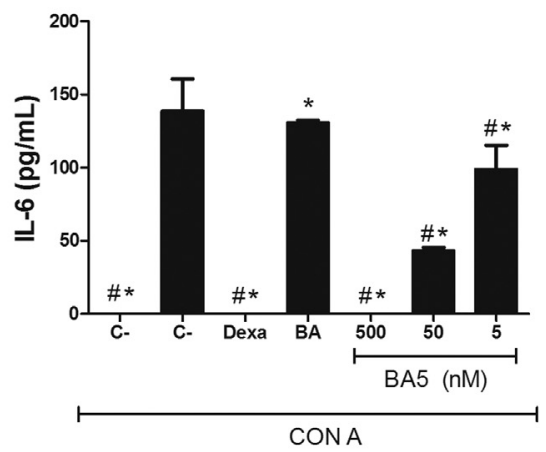

$\mathbf{F}$

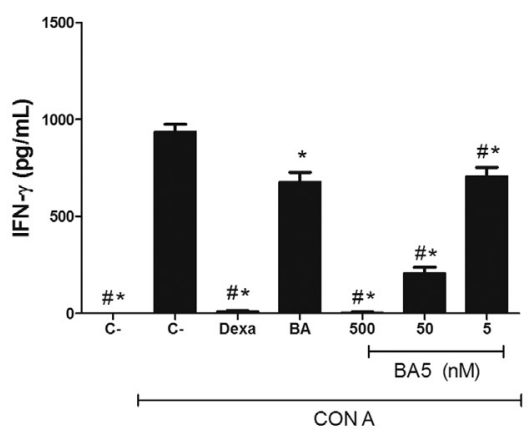

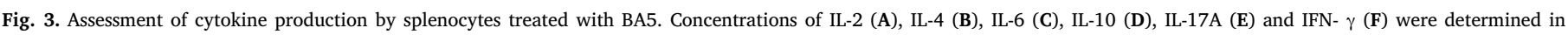

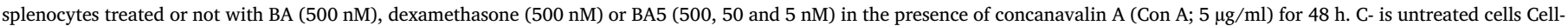

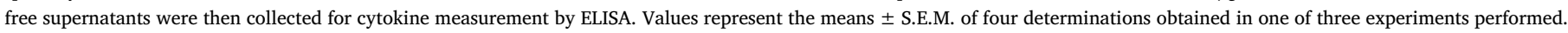
${ }^{*} P<0.05$ compared to stimulated and untreated cells; $\# P<0.05$ compared to BA-treated cells. 
A
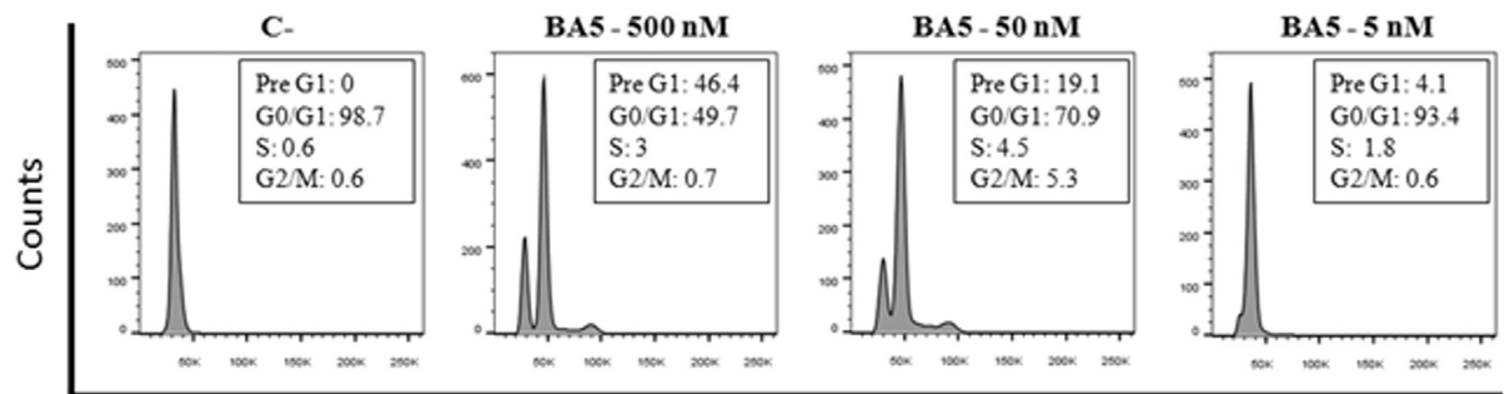

PI

B

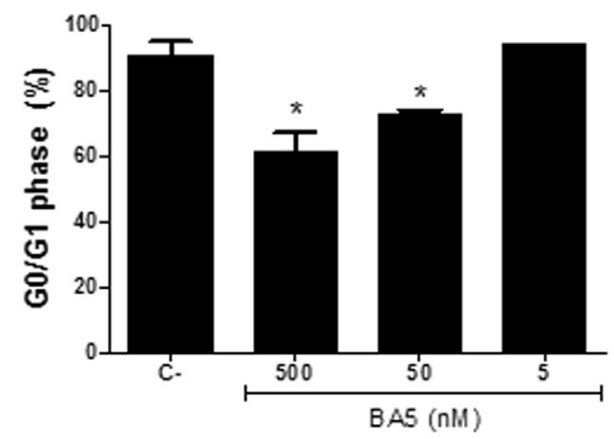

C

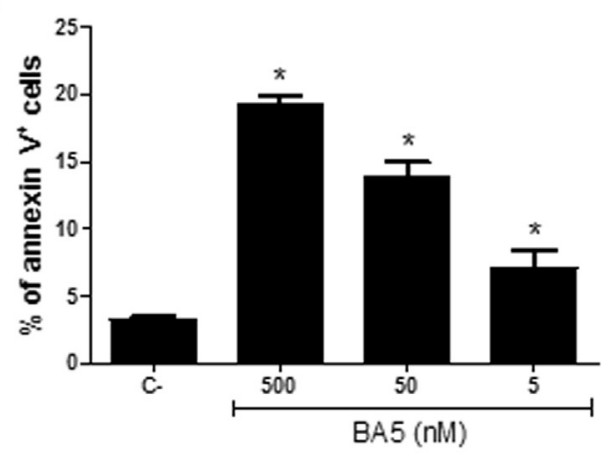

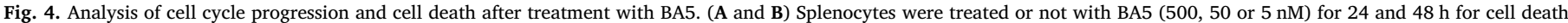

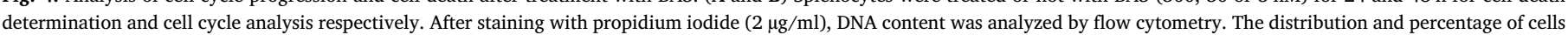

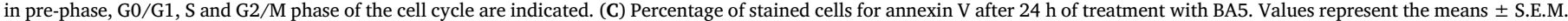
of four determinations obtained in one of two experiments performed. ${ }^{*} P<0.05$ compared to stimulated and untreated cells.

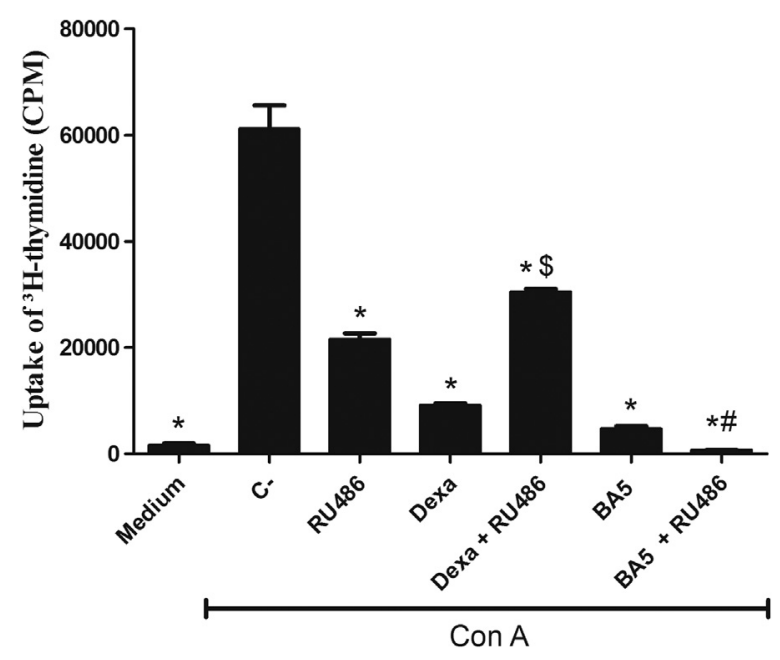

Fig. 5. Effects of RU486 on BA5 activity on Con A-induced lymphoproliferation. BALB/c splenocytes were stimulated with Con A alone or in the presence of dexamethasone (Dexa; $50 \mathrm{nM})$, BA5 $(50 \mathrm{nM})$ and RU486 $(10 \mu \mathrm{M})$. C- is untreated cells Proliferation was assessed $48 \mathrm{~h}$ later by ${ }^{3} \mathrm{H}$-thymidine incorporation. Values represent the means \pm S.E.M. of 4 determinations. ${ }^{*} P<0.05$ compared to Con $\mathrm{A} ; \# P<0.05$ compared to $\mathrm{BA} 5+$ Con $\mathrm{A}$; $\$ P<0.05$ compared to Dexa + Con A.

enzyme in a concentration-dependent manner, when compared to control untreated cultures. At $500 \mathrm{nM}$, BA5 caused the inhibition of calcineurin activity comparable to that of cyclosporin A, a reference inhibitor of calcineurin (Fig. 6).

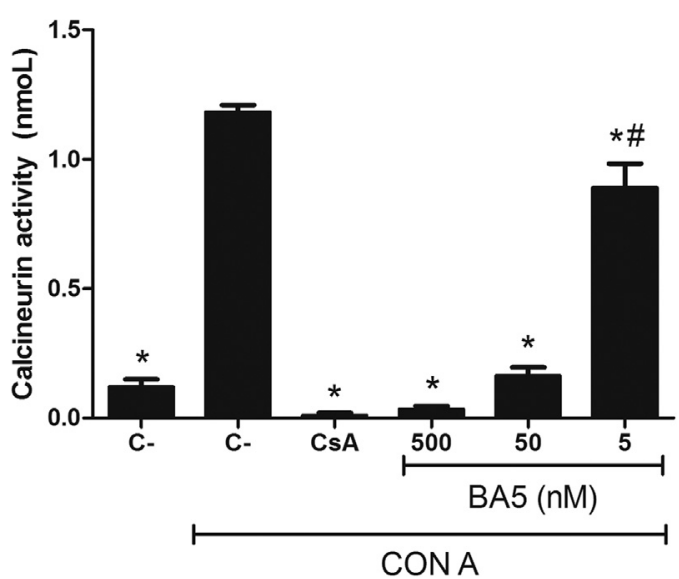

Fig. 6. BA5-based treatment inhibits calcineurin activity in a concentration-dependent manner. Spleen cells stimulated or not with Con A $(5 \mu \mathrm{g} / \mathrm{ml})$ were treated or not with different concentrations of BA5 $(500,50$ and $5 \mathrm{nM}$ ) or cyclosporin A (Csa; $500 \mathrm{nM}$ ) for $48 \mathrm{~h}$. C- is untreated cells Then, cells were lysed and cellular calcineurin phosphatase activity was measured in cell extracts, as described in the methods Values represent the means \pm S.E.M. of four determinations obtained in one of two experiments performed. $* P<0.05$ compared to stimulated and untreated cells; $\# P<0.05$ compared to cyclosporin A-treated cells.

\subsection{Synergistic effects of BA5 and dexamethasone}

Drug combinations are often employed in the clinical setting for treatment of immune-mediated diseases. Thus, we investigated the immunosuppressive effects of BA5 and dexamethasone in combination on lymphocyte proliferation induced by Con A. Compared to each drug 
Table 2

Concentration reductions and combination indexes for immunossupression by BA5 and dexamethasone.

\begin{tabular}{|c|c|c|c|c|c|c|}
\hline \multirow[t]{2}{*}{ Compounds } & \multicolumn{2}{|c|}{$\mathrm{IC}_{50} \pm$ S.E.M. $(\mathrm{nM})^{\mathrm{a}}$} & \multicolumn{2}{|c|}{$\mathrm{IC}_{90} \pm$ S.E.M. $(\mathrm{nM})^{\mathrm{a}}$} & \multicolumn{2}{|l|}{$\mathrm{CI}^{\mathrm{b}}$} \\
\hline & Drug alone & Combination & Drug alone & Combination & $\mathrm{IC}_{50}$ & $\mathrm{IC}_{90}$ \\
\hline BA5 & $13.7 \pm 0.9$ & $0.4 \pm 0.05$ & $205 \pm 7.7$ & $10 \pm 2.5$ & $0.13 \pm 0.01$ & $0.14 \pm 0.03$ \\
\hline Dexa & $4.2 \pm 0.1$ & $0.5 \pm 0.06$ & $76 \pm 8.7$ & $8.1 \pm 2.8$ & & \\
\hline
\end{tabular}

${ }^{\mathrm{a}} \mathrm{IC}_{50}$ and $\mathrm{IC}_{90}$ values were calculated using concentrations in quadruplicates and two independent experiments were performed.

b Combination index (CI). Cutoff: CI value of 0.1-0.7, synergism; 0.7-0.85, moderate synergism; 0.85-0.9, slight synergism; 0.9-1.1, additivity; > 1.1, antagonism. S.E.M. = standard error of the mean.

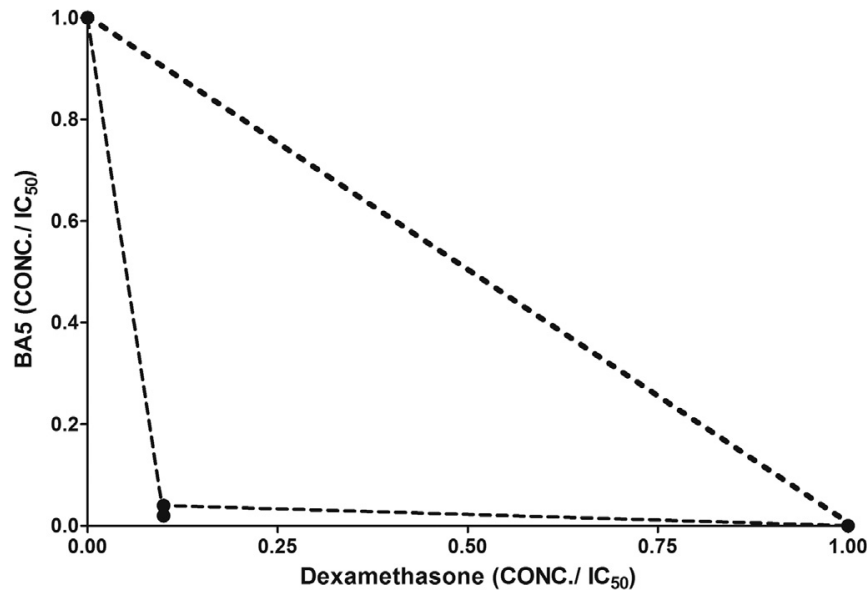

Fig. 7. Isobologram describing the synergistic effects of BA5 and dexamethasone on lymphocyte proliferation induced by Con A. Broken lines correspond to the predicted positions of the experimental points for additive effects.

alone, the combination of BA5 and dexamethasone reduced both $\mathrm{IC}_{50}$ and $\mathrm{IC}_{90}$ values. In fact, the $\mathrm{IC}_{50}$ and $\mathrm{IC}_{90}$ of both drugs decreased at least eight times (Table 2). The combination index values associated with a concave isobologram revealed that BA5 and dexamethasone have synergistic effects (Table 2; Fig. 7).

\subsection{BA5 protects mice against a lethal LPS challenge and reduces edema in} delayed-type hypersensitivity reaction

To investigate the effects of BA5 in a model of endotoxic shock, groups of BALB/c mice were treated with BA5 or vehicle (5\% of DMSO in saline) and challenged with a lethal dose of LPS. Treatment with $50 \mathrm{mg} / \mathrm{kg}$ BA5 induced protection to $83 \%$ of the animals (Fig. 8). Mice treated with BA5 at a lower dose $(25 \mathrm{mg} / \mathrm{kg})$ had, at the end of the observed period (four days), a survival rate of $33 \%$, similar to the vehicle-treated group. Administration of dexamethasone protected $100 \%$

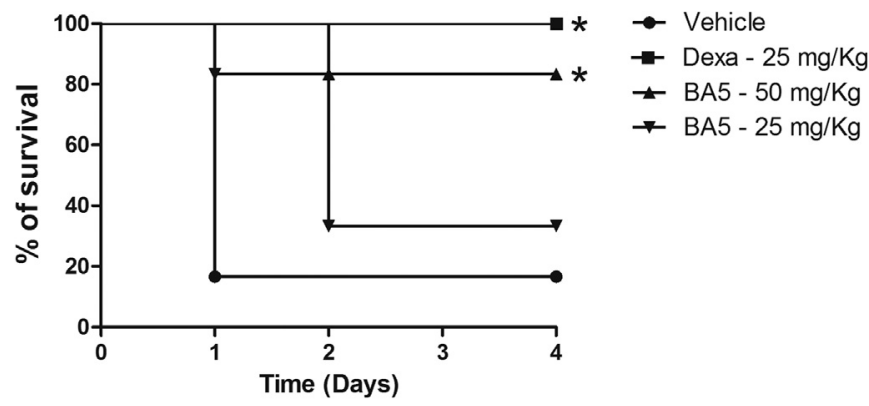

Fig. 8. Survival curve of mice treated with BA5 and submitted to endotoxic shock. Male $\mathrm{BALB} / \mathrm{c}$ mice $(\mathrm{n}=6)$ were treated with BA5 $(25$ and $50 \mathrm{mg} / \mathrm{Kg})$ or dexamethasone $(25 \mathrm{mg} / \mathrm{Kg}$ ) or vehicle (5\% DMSO in saline) and challenged with LPS $90 \mathrm{~min}$ later, intraperitoneally administered. Survival was monitored during 4 days after LPS challenge. Results are from one experiment of two experiments performed. ${ }^{*} P<0.05$ compared to vehicle group. Statistical analysis was carried out using Logrank (Mantel Cox).

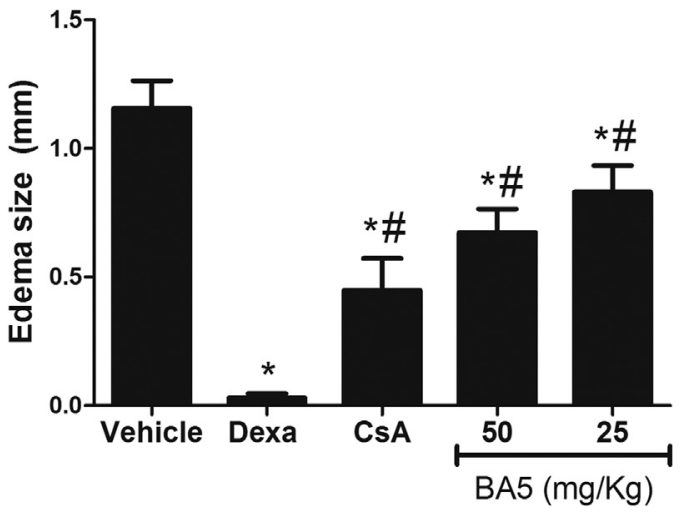

Fig. 9. BA5 reduces BSA-induced DTH in mice. Male BALB/c mice $(n=6)$ were treated with BA5 (25 and $50 \mathrm{mg} / \mathrm{Kg}$ ) or dexamethasone (Dexa; $25 \mathrm{mg} / \mathrm{Kg}$ ) or cyclosporin A (CsA; $25 \mathrm{mg} / \mathrm{Kg}$ ) or vehicle (5\% DMSO in saline) and challenged with $30 \mu \mathrm{l}$ of a $2 \%$ suspension of heat-aggregated BSA in saline administrated in the footpad. At $3 \mathrm{~h}$ post-challenge, footpad thickness was measured with calipers and the extent of swelling was calculated by subtracting the thickness of the footpad after challenge from that before challenge. Values represent the means \pm S.E.M. of six determinations obtained in one of two experiments performed. ${ }^{*} P<0.05$ compared to vehicle group; $\# P<0.05$ compared to dexamethasone group.

of animals at $25 \mathrm{mg} / \mathrm{kg}$. Animals from all groups displayed signs of shock, such as piloerection, shivering, and lethargy.

Finally, we investigated the effect of BA5 on BSA-induced DTH reaction in BALB/c mice. Following sensitization, groups of mice were treated with different doses of BA5 and thicknesses of paw measured before and after challenge were used as clinical signs of hypersensitivity. As shown in Fig. 9, treatment with BA5 at 50 and $25 \mathrm{mg} / \mathrm{kg}$ caused a reduction of paw edema of $41.7 \%$ and $27.8 \%$ respectively. Treatment with dexamethasone or cyclosporin A $(25 \mathrm{mg} / \mathrm{kg})$ caused a reduction of $97.4 \%$ and $61.7 \%$, respectively.

\section{Discussion}

Natural products are still a promising source for drug discovery through the continuous process of prospection of new compounds or synthesis of derivatives based on natural products (Newman and Cragg, 2016). This is exemplified by betulinic acid, a natural product with pleiotropic biologic effects and used successfully to generate more active compounds, such as antitumor and anti-HIV agents (Smith et al., 2007; Willmann et al., 2009; Ali-Seyed et al., 2016). In the present study, we investigated the immunomodulatory activity of amide semisynthetic betulinic acid derivatives containing substituents attached in the lupane backbone. We showed that the incorporation of an amide on C-28 enhanced the immunomodulatory effects on macrophage activation and lymphocyte function. The investigation led to the identification of a potent immunomodulatory agent, the semi-synthetic derivative BA5.

It is well-known that TNF $\alpha$ and NO play critical roles in inflammatory conditions. TNF $\alpha$ recruits and activates macrophages and T cells and modulates the secretion of other pro-inflammatory cytokines 
(Elenkov et al., 2005). Nitric oxide, due to its over production on inflammatory conditions, causes vasodilation (Xu et al., 2013). Here, we demonstrated a potent inhibitory activity of BA5 on TNF $\alpha$ and NO production in a concentration-dependent manner without affect cell viability in the tested concentrations. Consistent with these findings, BA5 also suppressed NF-KB activity, an important transcription factor that regulates several pro-inflammatory genes, such as TNF $\alpha$ (Lawrence et al., 2002). Moreover, the anti-inflammatory mechanism of BA5 differs from that of BA, the prototype molecule, which is IL-10 dependent (Fiorentino et al., 1991; Costa et al., 2014).

Although there are several reports about the anti-inflammatory activity of betulinic acid and its derivatives, little is known about the effects of these molecules on lymphocyte function. In the present work, we showed that betulinic acid is a potent inhibitor of lymphocyte proliferation and production of key cytokines in the proliferation and activation of lymphocytes, such as IL-2 and IFN $\gamma$ (Kohno et al., 1997; Boyman and Sprent, 2012). In addition, we showed that these properties are enhanced in BA5 derivative. In fact, the antiproliferative effect of BA and other terpenoids is well recognized in different tumor cell lines, especially in leukemia lineages, such as Jurkat cells, in which BA treatment induced cell cycle arrest in pre-G1 phase followed by cell death by apoptosis (Chen et al., 2008). Interestingly, a similar pathway of cell death was observed in lymphocytes treated with BA5. In addition, BA5 also potently inhibited calcineurin activity, an enzyme that plays a critical role in the progression of cell cycle and $\mathrm{T}$ lymphocyte activation through activation of NFAT (Rusnak and Mertz, 2000; Lipskaia and Lompré, 2004; Cen et al., 2013).

Despite the large number of immunosuppressive drugs available, most have side effects associated to a prolonged use and are not efficient in certain conditions (Garcia et al., 2004; Malvezzi et al., 2015). Combined drug therapy may be a valuable tool to improve treatment efficacy and reduce dose levels and toxicity immune disorders, as well as to prevent the potential development of resistance (Vedtofte et al., 2017; Kavishe et al., 2017). In our study, BA5 had synergistic effects with dexamethasone on the inhibition of lymphocyte proliferation, showing a promising profile for drug combination.

Previous studies detected the potential of betulinic acid and others triterpenoids in inflammatory mouse models (Costa et al., 2014; Niu et al., 2014; Lingaraju et al., 2015b). In the present work, we observed the effects of BA5 in a mouse model of endotoxemia induced through intraperitoneally LPS administration. In this model of lethal shock, LPS binds to CD14 receptors of macrophages and triggers the release of proinflammatory cytokines, including IL- 1 and TNF- $\alpha$ that can in turn induce lethal shock (Blank et al., 1997). Despite having protective effects in T-cell mediated shock models, classic calcineurin inhibitors such as cyclosporin A didn't have protective effects in LPS mediated shock models (Gonzalo et al., 1993). In contrast, BA5 proven to be a potent inhibitor of calcineurin and also able to protect animals from a lethal dose of LPS, showing a advantage when compared to others calcineurin inhibitors. We also observed a reduction of paw edema in a mouse model of BSA-induced DTH, a expected feature for a calcineurin inhibitor. Our results reinforce the potential use of betulinic acid and its derivatives in the searching for more potent and selective immunomodulatory drugs

In conclusion, betulinic acid can be successfully used for the generation of more active compounds, such as the derivative BA5, identified herein with a potent immunomodulatory in vitro and in vivo. BA5 also proved to be a suitable partner for drug combination, evidencing its potential use for the treatment of immune-mediated disorders.

\section{Conflict of interest}

All authors have no conflict of interest to disclose.

\section{Acknowledgements}

This work was supported by grants from CNPq (\# 400910/2013-6), PRONEX (\# PNX0002/2014) and FAPESB (\# PET0042/2013).

\section{References}

Ali-Seyed, M., Jantan, I., Vijayaraghavan, K., Bukhari, S.N., 2016. Betulinic acid: recent advances in chemical modifications, effective delivery, and molecular mechanisms of a promising anticancer therapy. Chem. Biol. Drug Des. 87 (4), 517-536.

Barbosa-Filho, J.M., Trigueiro, J.A., Cheriyan, U.O., Bhattacharyva, J., 1985. Constituents of the stem-bark of Ziziphus joazeiro. Nat. Prod. Res. 48, 152-153.

Bartuzi, P., Hofker, M.H., Sluis, B.V., 2013. Turning NF-kBactivity: a touch of COMMD proteins. Biochim. Biophys. Acta 1832 (12), 215-2321.

Blank, C., Luz, A., Bendigs, S., Endmann, A., Wagner, H., Heeg, K., 1997. Superantigen and endotoxin synergize in the induction of lethal shock. Eur. J. Immunol. 27, 825-833.

Blaževski, J., Petković, F., Momčilović, M., Paschke, R., Kaluđerović, G.N., Mostarica Stojković, M., Miljković, D., 2013. Betulinic acid regulates generation of neuroinflammatory mediators responsible for tissue destruction in multiple sclerosis in vitro. Acta Pharm. Sin. 34 (3), 424-431.

Boyman, O., Sprent, J., 2012. The role of interleukin-2 during homeostasis and activation of the immune system. Nat. Rev. Immunol. 12, 180-190.

Cen, J., Shi, M., Yang, Y., Fu, Y., Zhou, H., et al., 2013. Isogarcinol is a new immunosuppressant. PLoS One 8 (6), e66503.

Chen, S., Bai, Y., Li, Z., Jia, K., Jin, Y., et al., 2017. A betulinic acid derivative SH479 inhibits collagen-induced arthritis by modulating $\mathrm{T}$ cell differentiation and cytokine balance. Biochem. Pharmacol. S0006-2952 (16), 30368-30473.

Chen, Z., Wu, Q.L., Chen, Y., He, J., 2008. Effect of betulinic acid on proliferation and apoptosis in Jukart cells and its mechanism. Zhonghua Zhong Liu Za Zhi 30 (8), $588-592$.

Chien, C.H., Lai, J.N., Liao, C.F., Wang, O.Y., LM, L.U., Huang, M.I., Lee, W.F., Shie, M.C., Chien, E.J., 2009. Mifepristone acts as progesterone antagonist of non-genomic responses but inhibits phytohemagglutinin- induced proliferation in human T cells. Hum.Reprod. 24 (8), 1968-1975.

Chou, T.C., Talalay, P., 2005. Quantitative analysis of dose-effect relation-ships: the combined effects of multiple drugs or enzyme inhibitors. Adv. Enzym. Regul. 22, $27-55$.

Cichewicz, R.H., Kouzi, S.A., 2004. Chemistry, biological activity and chemotherapeutic potential of betulinic acid for the prevention and treatment of cancer and HIV infection. Med. Res. Rev. 24, 90-114.

Costa, J.F.O., Barbosa-Filho, J.M., Maia, G.L.A., Guimarães, E.T., Meira, C.S., Ribeiro-dosSantos, R., Carvalho, L.P., Soares, M.B.P., 2014. Potent anti-inflammatory activity of betulinic acid treatment in a model of lethal endotoxemia. Int. Immunopharmacol. 23, 469-474.

Dehelean, C.A., Feflea, S., Ganta, S., Amiji, M., 2011. Anti-angiogenic effects of betulinic acid administered in nanoemulsion formulation using chorioallantoic membrane assay. J. Biomed. Nanotechnol. 7 (2), 317-324.

Elenkov, I.J., Iezzoni, D.G., Daly, A., Harris, A.G., Chrousos, G.P., 2005. Cytokine dysregulation, inflammation and well-being. Neuroimmunomodulation 12, 255-269.

Fiorentino, D.F., Zlotnik, A., Mosmann, T.R., Howard, M., O'Garra, A., 1991. IL-10 inhibits cytokine production by activated macrophages. J. Imunnol. 147, 3815-3822.

Fivelman, Q.L., Adagu, I.S., Warhurst, D.C., 2004. Modified fixed-ratio isobolograma method for studying in vitro interactions between atovaquone and proguanil or dihydroartemisinin against drug-resistant strains of Plasmodium facilparum. Antimicrob. Agents Chemother. 48, 4097-4102.

Garcia, S.C., Lopes, L.S., Schott, K.L., Beck, S.T., Pombum, V.J., 2004. Cyclosporine A and tacrolimus: a review. J. Bras. Patol. Med. Lab. 40 (6), 393-401.

Gheorgheosu, D., Duicu, O., Dehelean, C., Soica, C., Muntean, D., 2016. Betulinic acid as a potent and complex antitumor phytochemical: a minireview. Anticancer Agents Med. Chem. 14 (7), 936-945.

Gonzalo, J.A., González-Garcín, A., Kalland, T., Hedlund, G., Martínez-A, C., Linomide, Kroemer G., 1993. a novel immunomodulator that prevents death in four model of septic shock. Eur. J. Immunol. 23, 2372-2374.

Green, L.C., Wagne, D.A., Glogowski, J., Skipper, P.L., Wishnok, J.S., Tannenbaum, S.R., 1982. Analysis of nitrate, nitrite, and [15N] nitrate in biological fluids. Anal. Biochem 126, 131-138.

Jingbo, W., Aimin, C., Qi, W., Xin, L., Huaining, L., 2015. Betulinic acid inhibits IL-1ßinduced inflammation by activating PPAR-y in human osteoarthritis chondrocytes. Int. Immunopharmacol. 29 (2), 687-692.

Kavishe, R.A., Koenderink, J.B., Alifrangis, M., 2017. Oxidative stress in malaria and artemisinin combination therapy: pros and cons. FEBS J. http://dx.doi.org/10.1111/ febs. 14097.

Kim, K.S., Lee, D.S., Kim, D.C., Yoon, C.S., Ko, W., Oh, W., Oh, H., Kim, Y.C., 2016. Antiinflammatory effects and mechanisms of action of coussaric and betulinic acids isolated from Diospyros kaki in lipopolysaccharide-stimulated RAW 264.7 macrophages. Molecules 21 (9), E1206.

Kohno, K., Kataoka, J., Ohtsuki, T., Suemoto, T., Okamoto, I., Usui, M., Ikeda, M., Kurimoto, M., 1997. IFN-gamma-inducing factor (IGIF) is a costimulatory factor on the activation of Th1 but not Th2 cells and exerts its effect independently of IL-12. J. Immunol. 158 (4), 1541-1550.

Lawrence, T., Willoughby, D.A., Gilroy, D.W., 2002. Anti-inflammatory lipid mediators and insights into the resolution of inflammation. Nat. Rev. Immunol. 123, 97-105.

Li, J., Goto, M., Yang, X., Morris-Natschke, S.L., Huang, L., Chen, C.H., Lee, K.H., 2016. 
Fluorinated betulinic acid derivatives and evaluation of their anti-HIV activity. Bioorg. Med. Chem. Lett. 26 (1), 68-71.

Li, J., Jing, J., Bai, Y., Li, Z., Xing, R., Tan, B., Ma, X., Qiu, W.W., Du, C., Du, B., Yang, F., Tang, J., Siwko, S., Li, M., Chen, H., Luo, J., 2017. SH479, a betulinic acid derivative, ameliorates experimental autoimmune encephalomyelitis by regulating the $\mathrm{T}$ helper 17/Regulatory T cell balance. Mol. Pharmacol. 91 (5), 464-474.

Lingaraju, M.C., Pathak, N.N., Begum, J., Balaganur, V., Bhat, R.A., Ramachandra, H.D., Ayanur, A., Ram, M., Singh, V., Kumar, D., Kumar, D., Tandan, S.K., 2015a. Betulinic acid attenuates lung injury by modulation of inflammatory cytokine response in experimentally-induced polymicrobial sepsis in mice. Cytokine 71 (1), 101-108.

Lingaraju, M.C., Pathak, N.N., Begum, J., Balaganur, V., Bhat, R.A., Ram, M., Singh, V., Kandasamy, K., Kumar, D., Kumar, D., Tandan, S.K., 2015b. Betulinic acid attenuates renal oxidative stress and inflammation in experimental model of murine polymicrobial sepsis. Eur. J. Pharm. Sci. 70, 12-21.

Lipskaia, L., Lompré, A.M., 2004. Alteration in temporal kinetics of $\mathrm{Ca} 2+$ signaling and control of growth and proliferation. Biol. Cell 96 (1), 55-64.

Macian, F., 2005. NFAT proteins: key regulators of T-cell development and function. Nat. Rev. Immunol. 5 (6), 472-484.

Malvezzi, P., Rostaing, L., 2015. The safety of calcineurin inhibitors for kidney-transplant patients. Expert Opin. Drug Saf. 14 (10), 1531-1546.

Meira, C.S., Barbosa-Filho, J.M., Lanfredi-Rangel, A., Guimarães, E.T., Moreira, D.R.M., Soares, M.B.P., 2016. Antiparasitic evaluation of betulinic acid derivatives reveals effective and selective anti-Trypanosoma cruzi inhibitors. Exp. Parasitol. 166, 108-115.

Newman, D.J., Cragg, G.M., 2016. Natural products as sources of new drugs from 1981 to 2014. J. Nat. Prod. 79 (3), 629-661.

Niu, X., Mu, Q., Li, W., Yao, H., Li, H., Huag, H., 2014. Esculentic acid, a novel and selective COX-2 inhibitor with anti-inflammatory effect in vivo and in vitro. Eur. J. Pharm. 740, 532-538.

Rusnak, F., Mertz, P., 2000. Calcineurin: form and function. Physiol. Rev. 80, 1483-1521. Smith, P.F., Ogundele, A., Forrest, A., Wilton, J., Salzwedel, K., Doto, J., Allaway, G.P., Martin, D.E., 2007. Phase I and phase II study of the safety, virologic effect, and pharmacokinetics/pharmacodynamics of single-dose 3-o-(3', $3^{\prime}$-dimethylsuccinly)betulinic acid (bevirimat) against human immunodeficiency virus infection.
Antimicrob. Agents Chemother. 51 (10), 3574-3581.

Soares, M.B.P., Brustolim, D., Santos, L.A., Bellintani, M.C., Paiva, F.P., et al., 2006. Physalins B, F and G, seco-steroids purified from Physalis angulata L., inhibit lymphocyte function and allogeneic transplant rejection. Int. Immunopharmacol. 6, 408-414.

Sultana, N., Saify, Z.F., 2012. Naturally occurring and synthetic agents as potential antiinflammatory and immunomodulants. Antiinflamm. Antiallergy Agents Med. Chem. 11 (1), 3-19.

Takada, Y., Aggarwal, B.B., 2003. Betulinic acid suppresses carcinogen-induced NF-kappa B activation through inhibition of I Kappa B alpha kinase and p65 phosphorylation: abrogation of cyclooxygenase-2 and matrix metalloprotease-9. J. Immunol. 17 (6), 3278-3286.

Titus, R.G., Chiller, J.M., 1981. A simple and effective method to asses murine delayed type hypersensitivity to proteins. J. Immunol. Methods 45, 65-78.

Vedtofte, L., Knop, F.K., Vilsboll, T., 2017. Efficacy and safety of fixed-ratio combination of insulin degludec and liraglutide (IDegLira) for the treatment of type 2 diabetes. Expert Opin. Drug Saf. 16 (3), 387-396.

Viji, V., Shobha, B., Kavitha, S.K., Ratheesh, M., Kripa, K., Helen, A., 2010. Betulinic acid isolated from Bacopa monniera (L.) Wettst suppresses lipopolysaccharide stimulated interleukin-6 production through modulation of nuclear factor-kappaB in peripheral blood mononuclear cells. Int. Immunopharmacol. 10 (8), 843-849.

Willmann, M., Wacheck, V., Buckley, J., Nagy, K., Thalhammer, J., Paschke, R., Triche, T., Jansen, B., Selzer, E., 2009. Characterization of NVX-207, a novel betulinic acidderived anti-cancer compound. Eur. J. Clin. Investig. 39 (5), 384-394.

Xu, J., Jia, Y.Y., Chen, S.R., Ye, J.T., Bu, X.Z., Hu, Y., Ma, Y.Z., Guo, J.L., Liu, P.Q., 2013 (E)-1-(4-ethoxyphenyl)-3-(4-nitrophenyl)-prop-2-en-1-one suppresses LPS-induced inflammatory response through inhibition of $\mathrm{NF}_{-\mathrm{kB}}$ signaling pathway. Int. Immunopharmacol. 15, 743-751.

Yogeeswari, P., Sriram, D., 2005. Betulinic acid and its derivatives: a review on their biological properties. Curr. Med. Chem. 12, 657-666.

Zhong, H., SuYang, H., Erdjument-Bromage, H., Tempst, P., Ghosh, S., 1997. The tran scriptional activity of NF-kappaB is regulated by the IkappaB-associated PKAc subunit through a cyclic amp-independent mechanism. Cell 89 (3), 413-424. 